\title{
Analysis Simultaneous Desulfurization and Denitration Technology for Glass Furnace Flue Gas
}

\author{
Shaohua Ling ${ }^{1, a}$, Changyong Jing ${ }^{1, b}$ \\ 1,Department of Environment Engineerring, Hebei University of Environmental Engineering, \\ Qinhuangdao,HeBei 066102 \\ ahb3412@163.com, 'xiaodier99@163.com
}

\begin{abstract}
Keywords:glass furnace;flue gas simultaneous desulfurization and denitration;analysis
Abstract:In this paper,according to the flue gas characteristics of glass melting furnace, combined with the existing glass melting furnace flue gas desulfurization and denitrification process. The analysis and discussion on the application of flue gas simultaneous desulfurization and denitrification technology in glass melting furnace are carried out.To 600T/D float glass furnace with heavy oil as fuel,the simultaneous desulfurization and denitrification technology solutions by NaCLO oxidation of flue gas in float glass furnace are studied on,and the economic and environmental benefits of this technology of flue gas in float glass furnace are analyzed.
\end{abstract}

\section{Foreword}

At present,China's regional atmospheric environmental problems are prominent,atmospheric haze phenomenon is prominent in some regional and urban,compound air pollution has become increasingly prominent. $\mathrm{SO}_{2}$ and $\mathrm{NO}_{\mathrm{x}}$ are currently major air pollutants, are the main cause of acid rain and photochemical smog. They have a serious impact on the ecological environment and human health ${ }^{[1]}$.In glass industry, air pollution is mainly derived from the furnace flue gas.At present, the flue gas treatment of domestic glass furnace is using separate desulfurization and denitrification process.That is,using wet desulfurization and SCR denitrification.However, this kind of traditional desulfurization and denitrification technology has the shortcomings of high investment,high operation cost and large area.Flue gas simultaneous desulfurization and denitrification technology has the advantages of equipment streamlined, small area and less investment ${ }^{[2]}$.Therefore, it is necessary to study simultaneous desulfurization and denitrification technology for glass furnace flue gas.

In this paper,aiming at the flue gas characteristics of glass melting furnace, the flue gas simultaneous desulfurization and denitrification technology are analyzed and discussed.The simultaneous desulfurization and denitrification technology solutions by NaCL0 oxidation of flue gas in float glass furnace are studied on,and the economic and environmental benefits of it are analyzed.

\section{Glass furnace flue gas characteristics}

At present in the domestic float glass industry,melting furnace fuel is mainly natural gas, heavy oil and so on.To 600T/D float glass furnace with heavy oil as fuel,flue gas flow is about $9.0-11 \times 10^{4} \mathrm{~m}^{3} / \mathrm{h}$, the smoke emission concentration of flue gas is about $100-300 \mathrm{mg} / \mathrm{m}^{3}, \mathrm{SO}_{2}$ emission concentration of flue gas is about $800-2000 \mathrm{mg} / \mathrm{m}^{3}, \mathrm{NO}_{\mathrm{x}}$ emission concentration of flue gas is about $1500-2500 \mathrm{mg} / \mathrm{m}^{3}$.

The $\mathrm{SO}_{2}$ in the flue gas of the glass furnace is comes from two aspects.First,the $\mathrm{S}$ in the fuel 
reacts with $\mathrm{O}_{2}$ to generate $\mathrm{SO}_{2}$ at the high temperature. Second,the sulfate in the glass raw material produces a small amount of $\mathrm{SO}_{2}$ at high temperature. The $\mathrm{SO}_{2}$ in the flue gas of the glass furnace is mainly from the fuel.

The $\mathrm{NO}_{\mathrm{x}}$ in the flue gas of the glass furnace is comes from three aspects:First,fuel type $\mathrm{NO}_{\mathrm{x}}$, the $\mathrm{N}$ in the fuel reacts with $\mathrm{O}_{2}$ to generate $\mathrm{NO}_{\mathrm{x}}$ at the high temperature.Second, thermal type $\mathrm{NOx}, \mathrm{N}_{2}$ and $\mathrm{O}_{2}$ of the air that into the glass melting furnace, generate $\mathrm{NO}_{\mathrm{x}}{ }^{[3-4]}$ at high temperatures. Third,raw material type $\mathrm{NO}_{x}$, the nitrate in the glass raw materials produce a small amount of $\mathrm{NOx}$ at high temperature. As the glass combustion temperature is as high as $1600-1800^{\circ} \mathrm{C}$, so the $\mathrm{NO}_{\mathrm{x}}$ in the flue gas of the glass furnace mainly is thermal type $\mathrm{NO}_{\mathrm{x}}{ }^{[5]}$.

\section{Simultaneous desulfurization and denitrification technology of glass furnace flue gas}

Simultaneous desulfurization and denitrification technology by activated carbon adsorption. This technology is that the adsorption of $\mathrm{SO}_{2}$ and $\mathrm{NO}_{\mathrm{x}}$ in the flue gas was carried out by activated carbon, using the characteristics of the void structure and the specific surface area of the activated carbon.The adsorption including physical adsorption and chemical adsorption ${ }^{[6]}$. The technology has the advantage of not producing secondary pollution,but the investment cost is high,the regeneration cost is big.In addition,the composition of glass melting furnace flue gas is complicated,thus restricting the development of activated carbon adsorption method in the field of simultaneous desulfurization and denitrification of glass furnace flue gas.

Simultaneous desulfurization and denitrification technology by pulsed corona method. This technology is that through the corona discharge to produce high-energy electrons, the use of high-energy electronic activation of oxidation, $\mathrm{SO}_{2}$ and $\mathrm{NO}_{\mathrm{x}}$ of flue gas are oxidized to sulfuric acid and nitric acid,and then react with $\mathrm{NH}_{3}$ to form ammonium sulfate and ammonium nitrate ${ }^{[7]}$.Simultaneous desulfurization and denitrification technology by pulsed corona method has the advantages of high efficiency of desulfurization and denitrification.But the power consumption is large,the power stability and safety control need to be improved,so in the actual application has some difficulties.

Simultaneous desulfurization and denitrification technology by ozone oxidation. This technology is that utilizing the strong oxidizing property of $\mathrm{O}_{3}, \mathrm{NO}$ in flue gas is oxidized to higher nitrogen oxides such as $\mathrm{NO}_{2}, \mathrm{~N}_{2} \mathrm{O}_{5}, \mathrm{NO}_{3}$ and so on. And then be absorbed by the lye, together with $\mathrm{SO}_{2}$ and $\mathrm{SO}_{3}$. Due to the high cost of ozone production, the application of this technology in simultaneous simultaneous desulfurization and denitrification of glass furnace flue gas is restricted.

Simultaneous desulfurization and denitrification technology by NaCLO oxidation. This technology is that $\mathrm{NaCLO}$ as the oxidant, $\mathrm{SO}_{2}$ and $\mathrm{NO}$ of the flue gas are oxidized to $\mathrm{SO}_{3}$ and $\mathrm{NO}_{2}$, and then be absorbed by the lye.Therefore, NaCLO oxidation method is more reasonable for the glass furnace flue gas simultaneous desulfurization and denitrification treatment.

Simultaneous desulfurization and denitrification technology solutions by NaCLO oxidation of flue gas in glass furnace

To 600T/D float glass furnace with heavy oil as fuel,the process system of simultaneous desulfurization and denitrification by NaCLO oxidation is mainly composed of absorption tower,flue gas system,absorbent preparation system,byproduct dehydration and storage system,oxidation fan system and automatic control system. The process is shown in Figure 1.

The flue gas of glass furnace is boosted by the booster fan,and cooled down by flue gas cooling system,enters the absorption tower.In the lime slurry tank by adding NaCLO solution, lime slurry and $\mathrm{NaCLO}$ solution are mixed evenly, the absorbent is sent to the absorption tower. When the absorbent is in contact with the flue gas, the $\mathrm{NO}$ in the flue gas is oxidized to $\mathrm{NO}_{2}$, and the $\mathrm{SO}_{2}$ and $\mathrm{NO}_{2}$ are absorbed to form $\mathrm{CaSO}_{3}$ and $\mathrm{Ca}\left(\mathrm{NO}_{2}\right)_{2}$. At the bottom of the absorption tower, $\mathrm{CaSO}_{3}$ and 
$\mathrm{Ca}\left(\mathrm{NO}_{2}\right)_{2}$ are oxidized to $\mathrm{CaSO}_{4}$ and $\mathrm{Ca}\left(\mathrm{NO}_{3}\right)_{2}$ by oxidizing air.CaSO 4 and $\mathrm{Ca}\left(\mathrm{NO}_{3}\right)_{2}$ slurry are saturated and crystallized,be sent to the dewatering system by discharging pump.By solid-liquid separation,gypsum and calcium nitrate solids are formed.

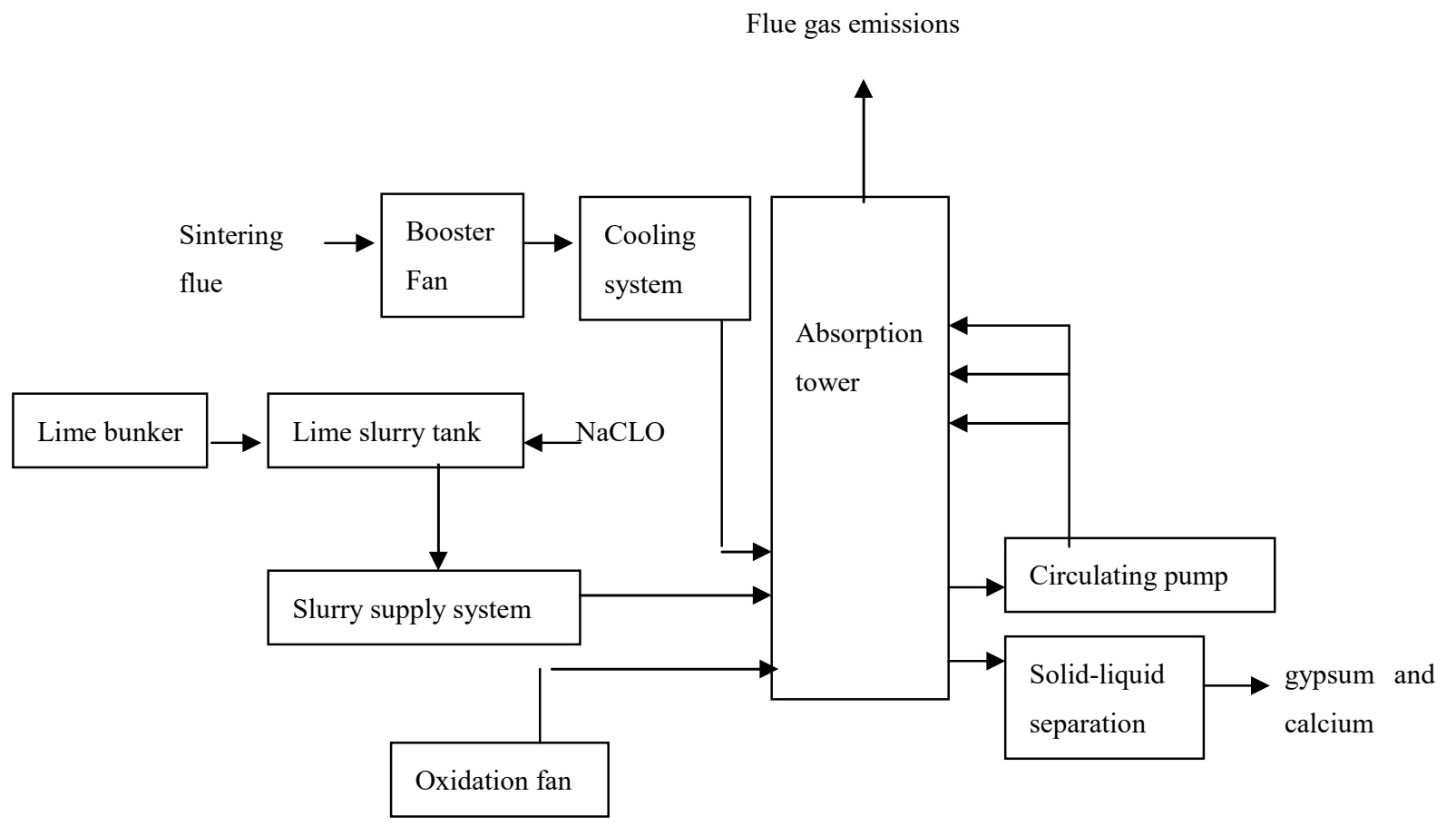

Figure 1 Process of simultaneous desulfurization and denitrification with NaCL0 oxidation

\section{Analysis of Economic and Environmental Benefits}

To $600 \mathrm{~T} / \mathrm{D}$ float glass furnace with heavy oil as fuel,flue gas flow is $11 \times 10^{4} \mathrm{~m}^{3} / \mathrm{h}, \mathrm{SO}_{2}$ emission concentration of flue gas is $1500 \mathrm{mg} / \mathrm{m}^{3}, \mathrm{NO}_{\mathrm{x}}$ emission concentration of flue gas is $2000 \mathrm{mg} / \mathrm{m}^{3}$.Desulfurization efficiency and denitrification efficiency are $90 \%$ and $70 \%$, respectively.

Analysis of economic benefits.Operating costs are mainly absorbent and power consumption.Operating costs are shown in Table 1.

Table 1 Operating cost statistics table

\begin{tabular}{c|c|c|c|c|c}
\hline No. & Name & Unit & Quatity & Cost & Remark \\
\hline 1 & Lime & $\mathrm{t} / \mathrm{a}$ & 3171 & 95 & 535 \\
\hline 2 & $\mathrm{NaCLO}$ & $\mathrm{t} / \mathrm{a}$ & 1673 & 110 & 32 \\
3 & Power consumption & $\mathrm{kw} / \mathrm{a}$ & 175 & 8 & \\
4 & Labor costs & number & 8 & 780 & \\
5 & Equipment maintenance & ten thousand yuan /a & & & \\
\hline
\end{tabular}

As shown in the above table,the total operating cost of the simultaneous desulfurization and denitrification system is 7.80 million yuan/year,equivalent to 1.98 yuan/heavy box(The melting point of the production line is $600 \mathrm{t} / \mathrm{d}$, the total yield is $90 \%$ ).

Analysis of environmental benefit.After the simultaneous desulfurization and denitrification project put into operation, desulfurization efficiency can be more than $90 \%$,denitrification 
efficiency can be more than 70\%.The annual reduction of $\mathrm{SO}_{2}$ emissions is about 1300 tons,reduction of $\mathrm{NO}_{\mathrm{X}}$ emissions is about 1340 tons.It is beneficial to improve the atmospheric environment where the glass production enterprise is located.Environmental benefits and social benefits are significant.

\section{Conclusions}

Simultaneous desulfurization and denitrification technology by NaCLO oxidation is suitable for glass melting furnace flue gas. The glass furnace flue gas is treated with this technology,can achieve "flat glass industry pollutant discharge standards" (GB26453-2011) requirements.At the same time can achieve the goal that the investment and operating costs are reasonable,the environmental benefits are obvious.

\section{Acknowledgements}

This work was financially supported by Hebei Science and Technology Research and Development Projects (15274019).Hebei colleges and universities of science and technology research projects (Z2015045).

\section{References}

[1]Chelluboyana V R,Mondal M K.Removal of $\mathrm{SO}_{2}$ and $\mathrm{NO}$ by com-plex absorbent using wet scrubbing[J].International Journal of Ap-plied Engineering Research,2014,9(3):345-350.

[2]Zhao Y,Hao R,Zhang P,et al.Integrative process for simultaneousr Removal of $\mathrm{SO}_{2}$ and $\mathrm{NO}$ utilizing a vaporized $\mathrm{H}_{2} \mathrm{O}_{2} / \mathrm{Na}_{2} \mathrm{~S}_{2} \mathrm{O}_{8}$ [J].Energy \& Fuels,2014,28(10):6502-6510.

[3]Liu Ke.Nitrogen oxide emission and control technology in glass melting furnace [J].China Glass, 2008 (3):33-36.

[4]Song Xueying,Xu Qian.Glass melting furnace gas treatment analysis[J]. Glass, 2007(5): 59-62.

[5]Mao lingwen,Lu Shaofeng.Nitrogen oxide contamination and treatment of flat glass melting furnace[J]. Proceedings of the Annual Meeting of Environmental Protection Branch of China Silicate Society,2009:336-341.

[6]Zhong Qin.Coal-fired flue gas desulfurization and denitrification technology and engineering examples [M].Beijing: Chemical Industry Press,2007:374-375.

[7]Liu Xiao.Coal-fired flue gas simultaneous desulfurization and denitrification technology research progress [J].Modern Chemical Industry,2015,35(10):25-29. 